\title{
The Impact of Currency Exchange Rates and Canadian and U.S. Unemployment Rates on Non-Immigrant Visas from Canada to the U.S.
}

\author{
W. Andrew Harrell \\ Jennifer A. Boisvert \\ Center for Experimental Sociology \\ University of Alberta \\ Edmonton, Alberta, Canada \\ E-mail: harandrw@aol.com
}

\begin{abstract}
Changes in immigration rates by Canadians from 1989 to 2006 were examined for three non-immigrant visa categories. Cross correlation functions (CCF) were calculated relating changes in numbers of visas to changes in Canada-U.S. currency exchange and unemployment rates. Regression analyses tested HanIbbott's (2005) model of immigration decision-making and a variation of Herrnstein's (1961) matching law. CCF analysis found that currency exchange and unemployment rates were predictive of changes in immigration rates. Regression analyses indicated that a devalued Canadian dollar discouraged migration to the U.S. These findings have implications for Canada-U.S. inequities in bilateral immigration under NAFTA, with Canada experiencing a greater drain in human capital.
\end{abstract}

Key Words: NAFTA, immigration, migration, currency exchange, unemployment 
Résumé

Nous avons examiné les changements dans les taux d'immigration chez les Canadiens entre 1989 et 2006 dans trois catégories de visas de non-immigrant. Les fonctions de corrélation croisée (FCC) ont étés calculées en reliant les nombres de changements de visas aux changements dans les taux d'échange canado-américains et le taux de chômage. Nous nous sommes servis d'analyses de régression pour tester le modèle de décision des politiques d'immigration de Han-Ibbott (2005) ainsi qu'une variation de la loi correspondante de Herrnstein (1961). L'analyse FCC a trouvé que le taux d'échange et le taux de chômage pouvaient prédire les changements de taux d'immigration. Les analyses de régression indiquent qu'un dollar canadien dévalué décourage la migration vers les États-Unis. Ces constatations ont des implications pour les iniquités dans les immigrations bilatérales canado-américaines sous l'ALENA, avec le Canada faisant l'expérience d'un plus haut taux de perte de capital humain.

Mots clés: ALENA, immigration, migration, taux d'échange, chômage

\section{NAFTA and Immigration}

Since the ratification of North American Free Trade Agreement (NAFTA) in 1994, there have been concerns that the "free" flow of workers between Canada, the United States (U.S.) and Mexico may adversely affect employment, particularly in the U.S. This link between migration and unemployment consequences has been explored in other studies (e.g., Marr and Siklos, 1994). The relatively few research studies investigating labor migration under NAFTA and its predecessor the Canada-U.S. Free Trade Agreement (FTA) appear to allay these concerns, at least for the U.S. Harper (1995) found that within 16 months of the FTA being implemented, there was a significant increase in U.S.based jobs because of increasing exports to Mexico. A more recent study (Dorantes and Huang, 1997) of U.S. unemployment rates in ten industries from 1983 through 1994 revealed that U.S. immigration from both Canada and Mexico was associated with decreases in U.S. unemployment. Migrant workers 
from Canada were found to be highly complementary to the U.S. labor force, enhancing economic productivity.

The picture is not as salutary for Canadians. From 1990 to1996 there was an almost $50 \%$ increase in migration of Canadian professionals to the U.S. compared to 1982 to 1989 . At the same time, there was a $40 \%$ drop in U.S. professionals coming to Canada (Globermann, 1999). Devoretz and Laryea $(1997,1998)$ estimated that from 1982 to 1996 , Canada incurred a net human capital deficit from this unequal bilateral migration of $\$ 6.7$ billion in the loss of professional and managerial talent. There is evidence that for every one U.S. citizen migrating to Canada, three Canadians emigrate to the U.S. (Iqbal, 2000).

The Han-Ibbott Model of Immigration. It is commonly believed that individuals will tend to migrate to countries where there is a better return on human capital than can be obtained in their home country. Human capital represents a person's skills, education, experience and monetary resources. In a recent Canadian study (Han and Ibbott, 2005) this economic model of immigration was used to explore relative preferences of Korean nationals for migration to the U.S. versus Canada from 1980 to 2002. Their model was based on previous studies of immigration and unemployment issues (e.g., Baker and Benjamin, 1996; Harris and Todaro, 1970). Han and Ibbott (2005) argued that higher rates of unemployment in a destination country, relative to either the home country or another destination for migration, would deter a move. Higher rates of unemployment in either the home country or destination country were reflective of poorer returns on human capital. A migrant, thus, should prefer countries with lower rates of unemployment because her/his work would be in greater demand and possibly more valued.

Han and Ibbott (2005) also hypothesized that fluctuations in currency exchange rates, specifically a devalued Canadian dollar, relative to the U.S. dollar, should result in a migratory preference for the U.S. Again, the underlying explanation was that countries with more valued currencies could offer more for a migrant's investment of labor and other assets.

Further to the above, in a series of multivariate analyses, Han and Ibbott (2005) tested the impact of changing unemployment rates and exchange rates on Korean immigration to the U.S. and Canada. Surprisingly, there was more Korean movement to Canada relative to the U.S. when the Canadian dollar was devalued. Furthermore, high U.S. unemployment increased rather than deterred migration to the U.S.

Autocorrelation and U.S. Immigration Policy. A number of problems were inherent in the data used in the Han and Ibbott model. The first was strong autocorrelation in the changes in immigration numbers from 1980 to 2002. Autocorrelation is a frequent problem for time series when there is dependency between values from year-to-year. This was a particular problem for the Han and Ibbott analysis since they focused on U.S. permanent residency visas awarded to Korean nationals. U.S. permanent residency visas are issued based 
on either family or employment petitions. In their analysis, Han and Ibbott (2005) were unable to distinguish between these two basic classes of visas and adjust for the fact that underlying motivational and decision-making factors will differ between them. For example, family-based petitions are less likely to be initiated because of economic considerations and more to affect family unity. Employment-based visas, on the other hand, are more likely to be impacted by currency exchange rates, unemployment and other indicia of economic wellbeing. Furthermore, the problem of year-to-year dependency or autocorrelation is typically built into U.S. permanent residency visas. These visas have annual quotas as well as regional chargeability biases, favoring countries that have not sent large numbers of immigrants to the U.S. in prior years while delaying the petitions of applicants from countries traditionally sending more immigrants. Immigrant visa categories that are oversubscribed or undersubscribed in any given year will, because of these quotas, impact the number of visas awarded in subsequent years.

In recognition of these problems confronting Han and Ibbott (2005), we have focused instead on non-immigrant visas that do not have similar quota restrictions that build in the same degree of autocorrelation. It has been observed that the number of permanent immigrations from Canada to the U.S. has dramatically dropped since 1971, with the bulk of Canadian migration being represented in temporary, non-immigration categories (Globermann, 1999). Virtually all of the non-immigrant visa categories have an economic basis, admitting temporarily individuals who can benefit the U.S. by investing financial resources or labor. It is our position that certain categories of nonimmigrant visas will be more sensitive to the economic factors identified by Han and Ibbott (2005).

NAFTA Professional (TN) Visa and Currency Exchange Rates. The uniquely North American visa impacting business migration within the hemisphere is the NAFTA Professional (TN) non-immigrant visa (see part 214 of United States Code of Federal Regulations, Title 8, Aliens and Nationality, 2008). The NAFTA Professional (TN) visa covers a wide range of professions (e.g., accountant, engineer, and professor) that were negotiated as part of NAFTA. Beneficiaries of this petition must have an employer endorse her/his application, indicating that the applicant is a Canadian citizen, has the necessary education (usually a post-secondary degree) or experience and training to qualify for an enumerated profession, and that they will be "temporary" workers for one year or less. The initial NAFTA Professional (TN) visa can only be obtained by the beneficiary at a U.S. port of entry after presenting her/his credentials and be approved by a NAFTA examiner employed by the U.S. Department of Homeland Security.

With respect to the NAFTA Professional (TN) visa, our general hypothesis was that a higher valued U.S. dollar would "push" Canadian workers to migrate to the U.S. Successful applicants for this category of NAFTA visas 
The Impact of Currency Exchange Rates and Canadian and U.S. Unemployment Rates on Non-Immigrant Visas from Canada to the U.S.

must have the threshold education or training that qualifies them to work and live in the U.S. Because of their greater skills, they should be the most impacted by the rewards offered in the U.S. Since there is some lead time required for a successful NAFTA Professional (TN) application, i.e., an employer must be located in the U.S., resumes drafted and proof of the prerequisite post-secondary degrees obtained, there will be some lag time. Thus, we hypothesized that a devalued Canadian dollar, i.e., a situation in which a U.S. dollar is above "par" or purchases more than one dollar in Canadian currency, in a given year may translate into an actual entry as a NAFTA Professional (TN) visa holder in the following year or later, i.e., a lag of one year or more.

NAFTA Professional (TN) Visa and Unemployment Rates. It was also hypothesized that unemployment rates in Canada and the U.S. should also impact non-immigrant visas. In the case of a NAFTA Professional (TN) visa, higher Canadian unemployment should encourage individuals to seek employment in the U.S. On the other hand, U.S. employers should be motivated to look outside the U.S. in those years where U.S. unemployment was low and local workers were scarce. Thus, there should be a positive relationship between Canadian unemployment rates and the number of NAFTA Professional (TN) visas, and a negative relationship between U.S. unemployment rates and the number of NAFTA Professional (TN) visas. Because of the steps outlined above that a Canadian job-seeker must undertake before successfully obtaining a visa, it was also hypothesized that fluctuations in unemployment rates would have a delay (lag) of one or more years.

Treaty Trader and Treaty Investor (E-1, E-2) Visas and Currency Exchange Rates. A second non-immigrant visa investigated in this study was the Treaty Trader and Treaty Investor (E-1, E-2) visas. The applicant for this category of NAFTA visas must be a Canadian citizen. She/he must develop a business plan, including detailed projections of expenses and revenues, as well as an indication of the potential to hire U.S. citizens or permanent residents. The Treaty Trader and Treaty Investor (E-1, E-2) visa application must be submitted to the appropriate U.S. consulate in Canada, along with evidence that the applicant has funding in place to ensure the success of her/his business. The applicant, if successful, will receive a visa entitling her/him to work and be paid by the U.S. venture as either a manager or person with specialized knowledge.

It was hypothesized that a poorly valued Canadian dollar, i.e., a Canadian dollar valued below par relative to the U.S. dollar, would have a strong impact on Treaty Trader and Treaty Investor (E-1, E-2) visa applications. A devalued Canadian dollar could reduce applications for these visas. The U.S. State Department has rigorous guidelines for successful applicants for the Treaty Trader and Treaty Investor (E-1, E-2) visas. The petitioner for this category of visa must have a minimal investment that is adequate for the nature and scope of her/his investment. This investment cannot be borrowed, and the investment must be placed in escrow, in U.S. funds. The visa processing is relatively rapid 
(6-8 weeks) and there is no requirement for a U.S.-based sponsor or petitioner to support the applicant's bid. Under this scenario, we hypothesized that a devalued Canadian dollar should be negatively correlated with the number of Treaty Trader and Treaty Investor (E-1, E-2) visas issued, with a possible time lag between the value of the Canadian dollar and a treaty application of one year.

Another scenario is that a strongly devalued Canadian dollar would motivate Treaty Trader and Treaty Investor (E-1, E-2) applicants to leave Canada because of the greater earning potential for their U.S. investment. In this case, there would be a positive correlation between exchange rates and numbers of Treaty Trader and Treaty Investor (E-1, E-2) visas.

Treaty Trader and Treaty Investor $(E-1, E-2)$ Visas and Unemployment Rates. In the case of Treaty Trader and Treaty Investor (E-1, E-2) visas, we believed that lower Canadian unemployment rates would signal a tight labor market, requiring that Canadian entrepreneurs pay higher wages. It was hypothesized that more Treaty Trader and Treaty Investor (E-1, E-2) visas would be issued when Canadian unemployment rates were low. Conversely, a fewer number of these visas would be applied for when Canadian unemployment rates were high and surplus Canadian workers permitted entrepreneurs to offer lower wages. With respect to the impact of U.S. unemployment rates, it was hypothesized that Canadian entrepreneurs would be more inclined to immigrate to the U.S. and invest in businesses when U.S. unemployment rates were relatively high, producing a surplus of workers. Because of the necessity to accumulate investment capital and to submit to the petitioning process, it was expected that a lag of at least one year between Canadian and U.S. unemployment rates and the numbers of Treaty Trader and Treaty Investor (E-1, E-2) visas would exist.

Intra-Company Transferee (L-1) Visa and Currency Exchange Rates. The Intra-Company Transferee (L-1) visa was the third category of nonimmigrant visas that were investigated. The application process for this category of NAFTA visas has been simplified for Canadians, permitting them to present a petition at a port of entry into the U.S. A Canadian can have the petition approved in a matter of minutes versus months of processing through one of the Immigration and Naturalization Service (INS) or United States Customs and Immigration Services (USCIS) centers. The petition must be sponsored by a U.S. affiliate of a Canadian employer. A case must be made that the Canadian has specialized knowledge or managerial experience that is needed by the U.S affiliate. It was hypothesized that there would be a positive relationship between currency exchange rates and the numbers of Intra-Company Transferee (L-1) visas issued; i.e., Canadian workers would be more motivated to seek a transfer to a U.S. subsidiary when the value of the U.S. dollar exceeded the value of the Canadian dollar; conversely, fewer Intra-Company Transferee (L-1) visas would be sought when the U.S. dollar value equaled the Canadian dollar value or 
dropped below it. No lags between currency exchange rates and the numbers of Intra-Company Transferee (L-1) visas issued were expected because of the relative simplicity and expedited nature of the petitioning process for Canadian workers and U.S. employers.

Intra-Company Transferee (L-1) Visa and Unemployment Rates. Since this transfer is ultimately initiated by a U.S. affiliated company trying to deal with employment needs in the U.S., it was expected that petitioning for an IntraCompany Transferee (L-1) visa would be most impacted by lower U.S. unemployment, requiring a petitioning U.S. employer to look to Canada to meet its labor requirements. Conversely, petitions would be fewer when U.S. unemployment rates were high, indicating that there may be adequate numbers of "local" workers to meet labor requirements. It was hypothesized Canadian unemployment rates would have a positive relationship to this visa, with Canadian firms less likely to relinquish their workers in times of low unemployment, and their Canadian employees more likely to welcome transfers when unemployment was high in Canada. It was hypothesized that there would be minimal lags between the impact of unemployment rates on Intra-Company Transferee (L-1) visas.

\section{The Herrnstein Model}

Han and Ibbott (2005) tested a nonlinear model based on the work of Baker and Benjamin (1996) that related the numbers of U.S. and Canadian immigrant visas acquired by Korean nationals to changes in currency exchange rates and Canadian and U.S. unemployment rates. In Han and Ibott's model, logarithmic transformations were made of the variables. In the present analysis, in addition to cross correlation function analysis, regressions analyses were carried out to adjust for possible confounding between the predictors. The form of the first regression is represented in equation (1):

$$
\ln (\text { numbers of visas })=\ln (k)+b \ln (E X)+b \ln (C U n)+b \ln (U S U n)
$$

In equation (1), $k$ is the intercept, $b$ is the unstandardized partial regression coefficient for each predictor, $E X$ is the currency exchange rate, $C U n$ is the Canadian unemployment rate, and USUn is the U.S. unemployment rate. The model in equation (1) is equivalent to Han and Ibbott's.

A second model has been suggested by Herrnstein's matching law research (Herrnstein, 1961). This law addresses human decision-making in concurrent operant situations where choices must be made between two or more alternatives, and has been applied frequently to economic decision-making (Foxall and James, 2003; Smith and Hantula, 2003). In the present study, the 
choice for Canadians was between migrating to the U.S., another country or staying in Canada. Herrnstein views the decision to choose between two alternatives, $A$ or $B$, as a function of the relative reinforcement or reward values associated with the two alternatives:

$$
B_{A} / B_{B}=k R_{A} / R_{B}
$$

The linear form of equation (2) is:

$$
\ln (A / B)=\ln (k)+b \ln \left(R_{A} / R_{B}\right)
$$

In our analysis we tested a Herrnstein-type model in which one of the terms was the ratio of Canadian and U.S. unemployment rates. The form of this implies that prospective migrants in making decisions will treat the respective unemployment rates as a ratio in which the "push" to emigrate because of high Canadian unemployment rate will be balanced against a possibly lower U.S. rate. The implication of this is that immigrants making decisions which psychologically factor the unemployment rates for the U.S. and Canada in terms of a ratio or "balance" between the two, whereas Han and Ibbott (2005) postulated that the decision-maker will take each unemployment rate as a separate, independent variable. The form of this equation is as follows:

$$
\ln (\text { Numbers of visas })=\ln (k)+\ln b(E X)+\ln b(C U n / U S U n)
$$

\section{Method}

Non-Immigrant Visa Data. Data for non-immigrant visas issued to Canadian residents in the years 1989 through 2006 were obtained from the U.S. Department of Homeland Security Statistical Yearbooks maintained by INS and its successor, USCIS (see Appendix). Data were not published for nonimmigrant visas in 1997; however estimates were made for this year by interpolating from years 1996 and 1998. Interpolation involved simply taking the mean of the visas for years 1996 and 1998. Three categories of nonimmigrant visas have been featured in this analysis: NAFTA Professional (TN), Treaty Trader and Treaty Investor (E-1, E-2), and Intra-Company Transferee (L-1).

Unemployment Rates and Currency Exchange Rates. U.S. and Canadian unemployment rates were obtained from the U.S. Bureau of Labor Statistics and Human Resources and Development Canada (see Appendix). Throughout the last 30 years, Canadian unemployment rates have annually surpassed U.S. rates. Part of this difference may be due to differences in the operational definition of unemployment in the two countries. To be unemployed in the United States one 
must have no job and be actively seeking employment (see Appendix). In Canada, to be classed as unemployment one must have no job and be seeking employment in any manner, including "passive" searches such as looking through job ads. Also, individuals who are not looking for work because they anticipate starting a job in the near future are not classified as unemployed in the U.S., but they are in Canada (Riddell, 2005).

Currency exchange rates from 1996 through 2006 were obtained from the Bank of Canada and OANDA.COM (see Appendix). The currency exchange rates reported in this article represent the conversion in Canadian currency for one U.S. dollar. For each year analyzed, one U.S. dollar exceeded in value its Canadian counterpart.

Time Series and Cross Correlation Functions. The cross correlation functions (CCF) gauge the linear association between measurements in two paired and equally spaced time series. We believe that this analysis is appropriate for calculating the degree of association between the time series changes in each of the three non-immigrant visa categories and the economic variables that may impact them: currency exchange rates, Canadian and U.S. unemployment rates. In the present case, the dependent variable series were the changes in each of the three categories of non-immigrant visas from 1989 through 2006. The units of analysis were each of the 18 years covered in this period of time. CCFs were calculated between each of these non-immigrant visa time series and currency exchange rates, Canadian and U.S. unemployment rates. The absolute value of each CCF was deemed to be statistically significant if it equaled or exceeded twice its estimated standard error. In the CCF analysis to follow, the largest CCFs have been reported and discussed, along with the lag, if any, for these CCFs.

In every time series analysis, there is a risk of autocorrelation or dependency between successive measurements. An analysis of autocorrelations for each of the non-immigrant visa categories was carried out, revealing significant time-based dependency for all three categories of visas, currency exchange rates, and Canadian and U.S. unemployment rates. This autocorrelation was corrected by calculating a difference between the number of NAFTA Professional (TN) visas issued in a given year and the number of visas issued in the previous year. This differencing process "de-trended" the data and achieved stationarity.

Following the CCF analysis, a series of regression analyses were carried out testing the two models specified earlier. These analyses used leading indicators for currency exchange rates and Canadian and U.S. unemployment rates that captured the significant lag effects noted in the $\mathrm{CCF}$ analysis, i.e., indicators whose value in the present time were good predictors of the dependent variables in a future period. When the largest CCF was not statistically significant, the non-lagged version of the variable was analyzed in the regression. Since the two regression models tested in this paper use 
logarithmic forms of the variables, the CCF analysis has also correlated variables that have this transformation.

\section{Results}

Descriptive Statistics. From 1989 through 2006, the mean exchange rate was $\$ 1.34$ Canadian for $\$ 1.00$ U.S. funds $(S D=0.14)$. The Canadian dollar was most devalued in 2002 when the exchange rate was \$1.57. In 2006 it reached its most "favorable" exchange at $\$ 1.13$. As shown in Figure 1, Canadian unemployment paralleled U.S. unemployment rates; however, for every year, Canadian rates were higher. Figure 1, however, also shows a narrowing of this gap over the 18year period. The mean Canadian unemployment was $8.03 \quad(S D=$ $1.84)$ versus $5.47(S D=0.95)$ for the U.S.

As shown in Figure 2, NAFTA Professional (TN) visas reached a high point in year 2000 of 110,740 . This has steadily decreased since 2001 . The mean number of annual NATFA Professional (TN) visas was 46,393.11 $(S D=$ $33,295.84)$. Intra-Company Transferee (L-1) visas have shown a slight increase, averaging $11,822.44$ visas per year $(S D=6,466.77)$. The Treaty Trader and Treaty Investor (E-1, E-2) visas have also slowly increased over time, with a high of 4,816 visas in $2006(M=3,125.94, S D=922.40)$.

\section{Cross Correlation Function Analysis}

Intra-Company Transferee (L-1). Table 1 presents the largest CCF from each analysis. In Table 1 , it was predicted that the number of Intra-Company Transferee (L-1) visas would be greater in years featuring a devalued Canadian dollar, i.e., with a zero-year lag. This prediction was supported. There was a significant positive correlation between currency exchange rates and number of Intra-Company Transferee (L-1) visas, and this CCF for this visa was without a lag, i.e., the CCF represented a correlation between the number of IntraCompany Transferee (L-1) visas and currency exchange rates in a given year.

Canadian and U.S. unemployment rates were not significantly related to this visa. The general tendency, however, was for greater numbers of IntraCompany Transferee (L-1) visas to be issued following years (seven-year lag) of high unemployment in Canada and low employment in the U.S. (four-year lag). The ratio of the two unemployment rates was positive suggesting that higher ratios, e.g., when Canadian unemployment increased, relative to U.S. unemployment, were associated with more Intra-Company Transferee (L-1) visas. The directions of the CCFs were consistent with our hypotheses. However, the presence of lagged relationships for the effect of unemployment was not consistent. 
The Impact of Currency Exchange Rates and Canadian and U.S. Unemployment Rates on Non-Immigrant Visas from Canada to the U.S.

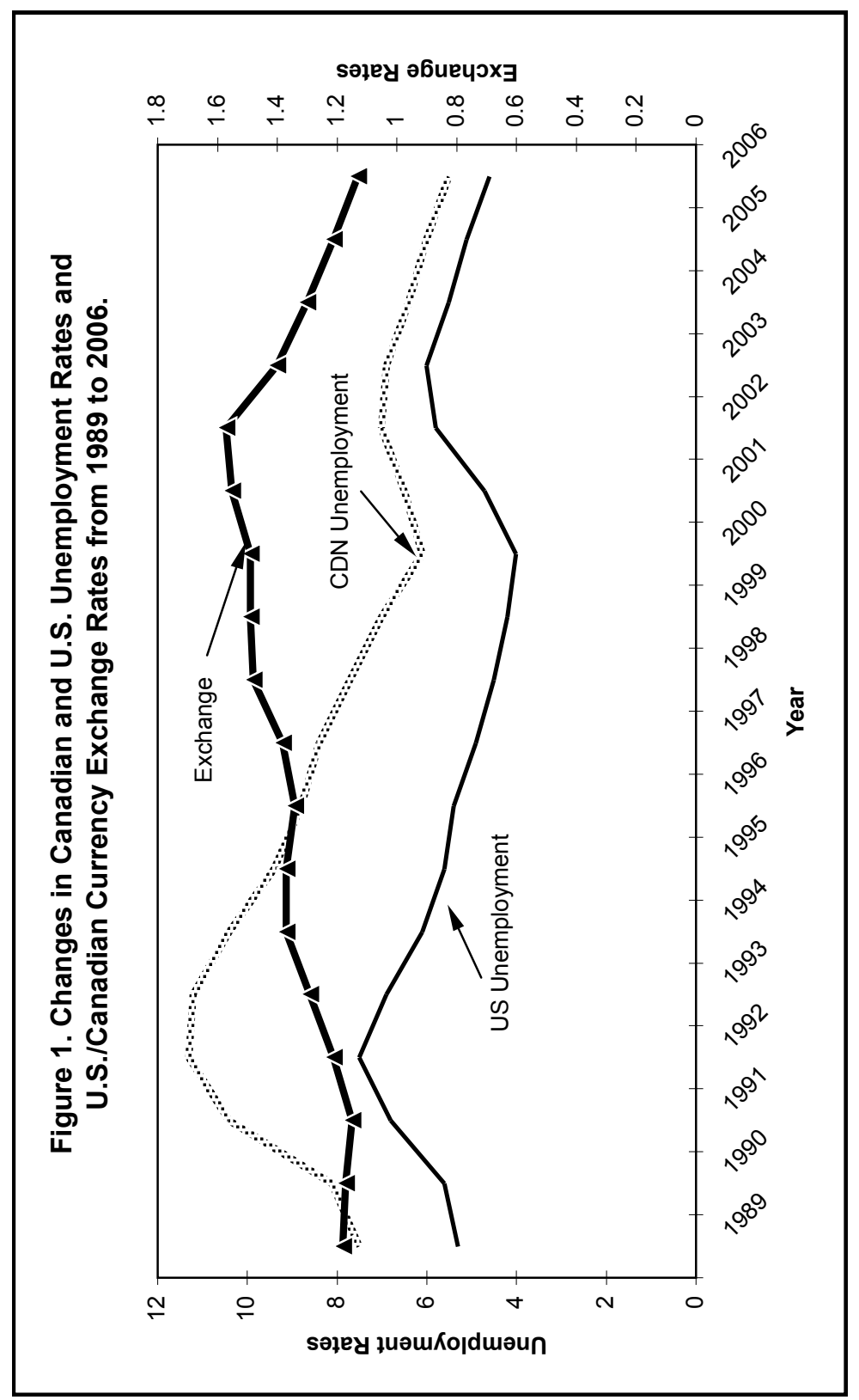




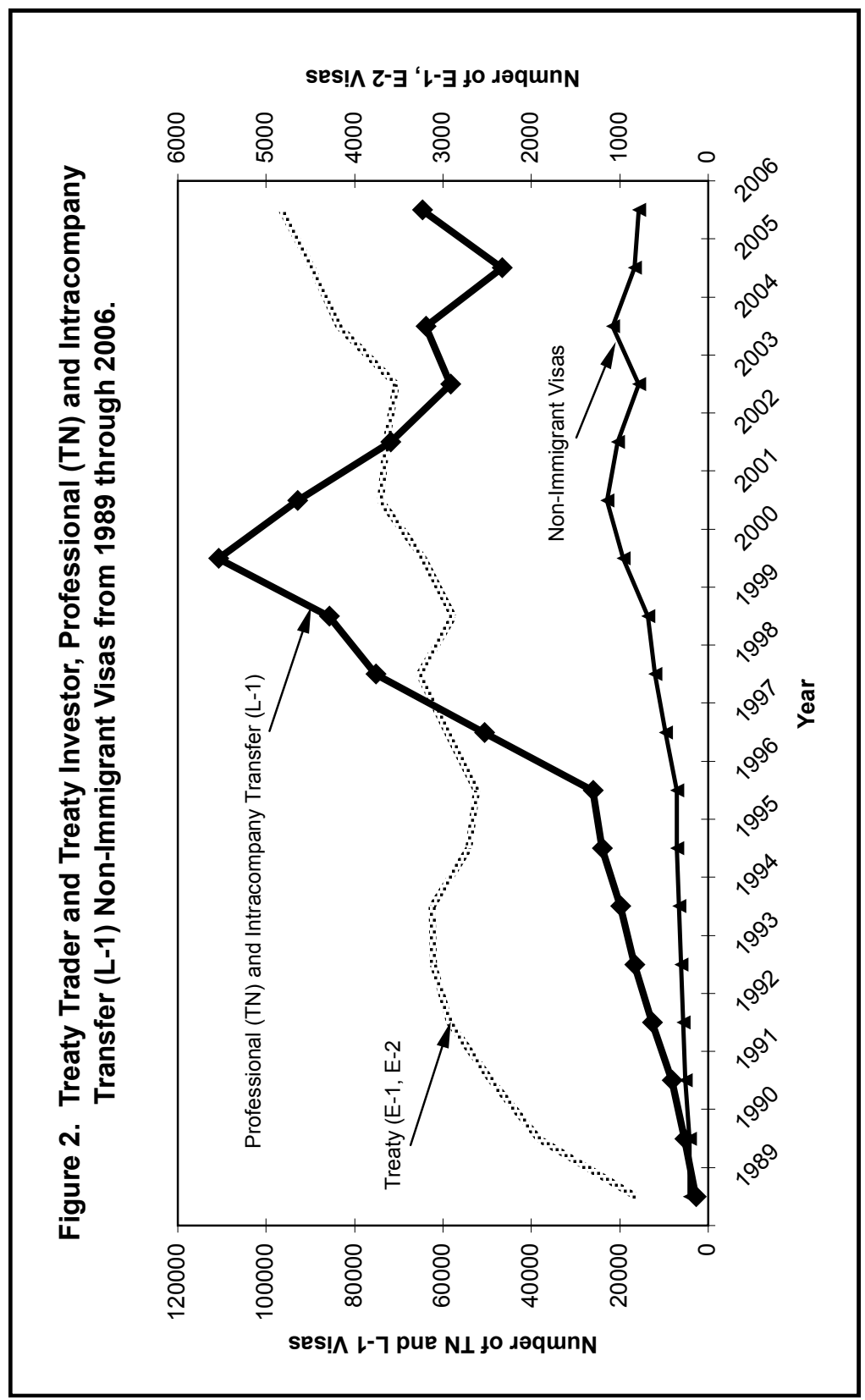

CSP 2009, 36.3-4: 217-236 
The Impact of Currency Exchange Rates and Canadian and U.S. Unemployment Rates on Non-Immigrant Visas from Canada to the U.S.

Treaty Trader and Treaty Investor (E-1, E-2). As shown in Table 1, currency exchange rates had a positive, statistically significant relationship with Treaty Trader and Treaty Investor (E-1, E-2) visas, with a lag of one year. That is, a devalued Canadian dollar decreased applications for Treaty Trader and Treaty Investor (E-1, E-2) visas. This finding was consistent with our hypothesis that the "costs" of amassing the necessary investment capital would be greater in times of a devalued Canadian dollar, resulting in fewer Treaty Trader and Treaty Investor (E-1, E-2) visa applications. Higher Canadian and U.S. unemployment rates both were associated with decreases in this category of visa. In addition, a negative ratio of unemployment rates indicated that relatively lower Canadian unemployment motivated more applicants for this category of visa. Lower Canadian unemployment likely motivated entrepreneurs to stay in Canada, while relatively higher U.S. unemployment lead to investment and moves to the U.S.

NAFTA Professional (TN). Table 1 shows that currency exchange rates had the predicted positive relationship to NAFTA Professional (TN) visas, but a zero-year lag. Canadian unemployment had the predicted negative relationship, with greater numbers of NAFTA Professional (TN) visas being issued following years (six-year lag) of high Canadian unemployment. The significant ratio of unemployment rates indicates that relatively higher Canadian unemployment compared to lower U.S. unemployment was correlated with larger numbers of this visa being sought and issued.

\section{Regression Analyses}

Regression analyses were carried out for all three of the visa categories. Because of autocorrelation, each visa category was modified to a difference form to correct for this problem. In addition, because of the lagged effects noted in the CCFs, currency exchange rates, Canadian and U.S. unemployment rates, and the ratio of unemployment rates were converted to lagged forms in cases where the CCFs were statistically significant. When these CCFs were not significant, then no lag was calculated.

The Han-Ibbott model, shown in the upper half of Table 2, explained $32 \%$ of the variance in the non-immigrant NAFTA visas. Canadian and U.S. unemployment rates had significant relationships, with higher Canadian unemployment being positively related to numbers of visas, and U.S. unemployment rates being negative. This is consistent with our prediction that higher Canadian unemployment would motivate Canadian skilled workers to seek jobs in the U.S. A situation of lower U.S. unemployment would result in U.S. employers seeking Canadian workers for unfilled positions. Currency exchange rate was positively related to NAFTA Professional (TN) visas, but not statistically significant. 
The Herrnstein model for non-immigrant NAFTA visas explained only $5 \%$ more of the variance than the Han-Ibbott model. Currency exchange rates were not statistically significant in this model, but higher ratios of Canadian versus U.S. unemployment resulted in greater numbers of NAFTA Professional (TN) applications in a given year.

Table 1

Observed Cross Correlation Functions and Lags

\begin{tabular}{|c|c|c|c|}
\hline \multirow{2}{*}{ Variable } & \multicolumn{3}{|c|}{ Visa Category } \\
\hline & E-1, E-2 & L-1 & $\mathbf{T N}$ \\
\hline $\begin{array}{l}\text { CDN/U.S. Exchange } \\
\text { Rate } \\
\text { CDN Unemployment } \\
\text { Rate } \\
\text { U.S. Unemployment } \\
\text { Rate } \\
\text { CDN/U.S. Unemployment } \\
\text { Rate }\end{array}$ & $\begin{array}{c}-.53 *(.26) \\
\mathrm{Lag}=1 \text { year } \\
-.33(.25) \\
\mathrm{Lag}=0 \text { years } \\
-30(.25) \\
\mathrm{Lag}=0 \text { years } \\
-.39(.27) \\
\mathrm{Lag}=0 \text { years }\end{array}$ & $\begin{array}{c}.47 *(.23) \\
\mathrm{Lag}=0 \text { years } \\
.43(.32) \\
\mathrm{Lag}=0 \text { years } \\
-.38(.28) \\
\mathrm{Lag}=0 \text { years } \\
.46(.27) \\
\mathrm{Lag}=0 \text { years }\end{array}$ & $\begin{array}{c}.38(.26) \\
\mathrm{Lag}=0 \text { years } \\
.48(.34) \\
\mathrm{Lag}=0 \text { years } \\
.41(.32) \\
\mathrm{Lag}=0 \text { years } \\
.58 *(.24) \\
\mathrm{Lag}=0 \text { years }\end{array}$ \\
\hline
\end{tabular}

The Han-Ibbott model accounted for $57 \%$ of the adjusted variance in Treaty Trader and Treaty Investor (E-1, E-2) visas. This was 2\% less than the Herrnstein model. Currency exchange rates were the only statistically significant factor. The strong negative relationship between this variable and numbers of Treaty Trader and Treaty Investor (E-1, E-2) visas confirmed our belief that a devalued Canadian dollar may have made it difficult for Canadian entrepreneurs to amass an investment "stake" that met U.S. State Department guidelines for "at risk" capital. It should be noted that the impact of currency exchange rates is lagged by one year for the Treaty Trader and Treaty Investor (E-1, E-2) visas, reflecting the amount of preparation needed for this category of visa. The lack of 
significance for Canadian and U.S. unemployment indicates that they may be less relevant factors when entrepreneurs are considering a move to the U.S.

With respect to the Intra-Company Transferee (L-1) visas, the two models are of equal predictive power, with the Han-Ibbott model accounting for $17 \%$ of the adjusted variance and the Herrnstein model, 18\%. In the Han-Ibbott model, higher U.S. unemployment rates were associated with lower numbers of IntraCompany Transferee (L-1) visas. This is most likely due to U.S. employers having sufficient local candidates for employment and to U.S. immigration officials declining Intra-Company Transferee (L-1) applications to protect a fragile U.S. workforce. The significant unemployment ratio in the Herrnstein model shows that relatively higher Canadian unemployment was predictive of subsequent Intra-Company Transferee (L-1) visas. The optimal situation for Intra-Company Transferee (L-1) visa applications would be high Canadian unemployment motivating Canadian workers to seek employment with U.S. affiliates, and low U.S. unemployment, precluding U.S. employers from filling job vacancies with local talent.

Table 2

Regression Analyses (Standardized Regression Coefficients) for Han-Ibott and Herrnstein-Type Models

\begin{tabular}{|c|c|c|c|}
\hline \multirow{2}{*}{ Variable } & \multicolumn{3}{|c|}{ Visa Category } \\
\hline & E-1, E-2 & L-1 & $\mathbf{T N}$ \\
\hline CDN/U.S. Exchange Rate & $-.75^{*}$ & .03 & .33 \\
\hline CDN Unemployment Rate & .28 & $.77^{*}$ & $.97 *$ \\
\hline \multirow[t]{2}{*}{ U.S. Unemployment Rate } & $-.81 *$ & -.27 & $-1.06^{*}$ \\
\hline & $R^{2}=.57$ & $R^{2}=.17$ & $R^{2}=.32$ \\
\hline CDN-U.S. Exchange Rate & $-.78 *$ & $.11 *$ & .33 \\
\hline \multirow[t]{2}{*}{ CDN-U.S. Unemployment Rate } & .65 & $.50 *$ & $.55 *$ \\
\hline & $R^{2}=.59$ & $R^{2}=.18$ & $R^{2}=.37$ \\
\hline
\end{tabular}




\section{Discussion}

This study demonstrates the importance of three variables - currency exchange rates, Canadian unemployment rates and U.S. unemployment rates - in explaining variations in the use of non-immigrant visas by Canadians migrating on a temporary basis to the U.S. from 1989 through 2006. Three employmentbased non-immigrant visas were investigated: NAFTA Professional (TN), Treaty Trader and Treaty Investor (E-1, E-2), and Intra-Company Transferee (L1). The NAFTA Professional (TN) was by far the largest non-immigrant visa category, averaging more than 46,000 visas per year. As described above, CCFs were calculated relating changes over time in each of the non-immigrant visa categories with exchange rates and unemployment rates. Two models were tested. One model had been recently been applied recently by Han and Ibbott (2005) to account for differential migration of Koreans to the U.S. and Canada. A second model was derived from Herrnstein's (1961) matching law.

These two models were best at explaining changes in the Treaty Trader and Treaty Investor $(\mathrm{E}-1, \mathrm{E}-2)$ visas $\left(R^{2}=.57-59\right)$ and next best for the Professional NAFTA (TN) visa $\left(R^{2}=.32-37\right)$. The models were weakest for the Intra-Company Transferee visas $(\mathrm{L}-1)\left(R^{2}=.17-.18\right)$. By a slight margin, the Herrnstein model was superior to the Han-Ibbott model. Herrnstein (1961) uniquely conceptualized decisions to migrate based on the ratio of reinforcement or rewards for making a particular choice. In the present case, the Herrnstein model argues that decisions to leave Canada or remain are a function of the ratio of Canadian and U.S. unemployment rates. In contrast, in the Han-Ibbott model these two rates of unemployment work separately. With respect to the Herrnstein model, higher Canadian unemployment is a "push" factor, encouraging Canadians to leave their country. Lower U.S. unemployment is a "pull" factor, both for the Canadian worker seeking better job prospects in the U.S. and for the U.S.-based employer coping with a small supply of prospective workers.

The data give a slight edge to the Herrnstein view that that relative differences in Canadian and U.S. unemployment rates are critical in explaining variations in numbers of NAFTA Professional (TN) visas, with higher Canadian unemployment appearing to motivate Canadians to migrate to the U.S. to work and lower U.S. unemployment rates motivating U.S.-based employers to search for employees outside of the U.S. A similar mechanism seems to be at work in the case of Intra-Company Transferee (L-1) visas, as well. Canadians faced with relatively high unemployment in Canada are more likely to petition to transfer to a U.S. affiliate. U.S. affiliates, in turn, are more receptive to "importing" Canadian employees in times of low unemployment in the U.S. 
being sought or issued. Plainly, a devalued Canadian dollar works against the Canadian entrepreneur who must amass a significant nest egg of capital before she/he is eligible for the visa, increasing the costs of securing the investment "nest egg" required to persuade the U.S. State Department that a viable business can be opened in the U.S. The importance of currency exchange rates for this non-immigrant visa was not surprising since the major barrier to approval of a visa application has typically been obtaining sufficient at-risk capital.

There was a non-significant tendency for a devalued Canadian dollar to increase the number of NAFTA Professional (TN) and Intra-Company Transferee (L-1) visas. Presumably, this positive relationship reflects the fact that Canadian workers are motivated to leave for the U.S. where their skills may enable them to earn higher salaries and more highly valued U.S. dollars.

This study also documents the need to be sensitive to lag effects when explaining patterns of migration. Han and Ibbott (2005) did not consider lag effects in their analysis of permanent residency visas, ignoring the fact that the petitioning process can take years to complete. Migration to the U.S. can no longer be done on a whim, particularly since the $9 / 11$ terrorist attacks. While NAFTA has streamlined the process for Canadians, a successful immigrant still must obtain a U.S. employer who will make a case for her/his employment. The necessary supporting documents, e.g., resumes, degrees and letters of recommendation, must be gathered and a formal petition or application developed. Successful immigration takes time, and this is why the impact of currency exchange and unemployment rates will be at least one year in the future. The impact of differential currency exchange and unemployment rates in our study convincingly show that current numbers of non-immigrant visas are the outcome of economic factors of a year or more in the past. This was especially the case with the Treaty Trader and Treaty Investor (E-1, E-2) visas where there may be a lagged time to amass a threshold amount of investment capital in U.S. funds.

This study also points to the obvious fact that if one wishes to investigate the impact of economic variables on immigration, then more success will be achieved by looking at immigration categories that are strictly employmentbased. It is not surprising that Han and Ibbott (2005) had difficulties with their analysis because they looked at changes in immigrant visas - the majority of which were family unity rather than employment-based. Similarly, we would expect our economic variables to have weaker predictive power in explaining changes in student, religious worker, or exchange visitor visas which are less clearly business in nature.

It should be pointed out that other factors that have not been measured in this study might influence migration decisions. These factors include a desire to live in a warmer climate or recreational/cultural assets present in the U.S. that may be absent in Canada. They also include other lifestyle or standard-of-living factors that might better have been measured by indicia such as gross domestic 
product (GDP). The lures of higher incomes in the U.S., along with lower personal taxes, have not been accounted for in our analysis; nevertheless, they should be powerful considerations, especially for NAFTA Professional (TN) and Intra-Company Transferee (L-1) visa applicants. Iqbal (2000) tested an economic model examining the impact of Canadian-U.S. differences in income, taxes and unemployment on emigration to the U.S. from 1986 to 1997. These three difference scores accounted for $72 \%$ of the variance in migration decisions. The fact that the models tested in this article were less powerful in accounting for variations in the numbers of NAFTA Professional (TN) or IntraCompany Transferee (L-1) category visas is revealing since there are two decision-makers involved in both of these visas: the petitioner and the beneficiary or recipient of the visa. While purely economic variables might be salient for the petitioning employer, the unmeasured factors mentioned above may have a greater influence on the Canadian worker seeking to move. In the case of the Treaty Trader and Treaty Investor (E-1, E-2) visas, however, there is only one decision-maker: the petitioning entrepreneur. Because this class of visas is designed to appeal to business people, then other considerations, e.g., lifestyle, may be of lower importance.

Finally, previous patterns of bilateral migration in North America document the reality that Canada has been disadvantaged, given the large scales losses of professional and managerial talent under NAFTA and the previous U.S.-Canada Free Trade Agreement (FTA). Our study indicates that this "brain drain," as well as loss of investment capital with the emigration of traders and investors, is dependent on differences in currency and employment between the two countries. With the increased value of the Canadian dollar over the last two years, this may decrease the costs of entrepreneurs moving to the U.S. Conversely, a Canadian dollar that is on par with the U.S. dollar may "lure" U.S. professionals to migrate to Canada under NAFTA. A case can also be made that a Canadian dollar that is valued less than its U.S. counterpart may encourage lower Canadian costs of production for products that are subsequently exported; these lower costs of production may enhance Canadian job creation and reduce the attractiveness of migrating to the U.S. under NAFTA. Unless the historical unemployment gap between Canada and the U.S. continue to narrow, there will continue to be an incentive for Canadians to take advantage of greater employment opportunities in the U.S.

\section{End Note:}

1. Prior to 1994, Canadian Professional workers were admitted to the U.S. under the Canada - Free Trade Agreement (FTA). The professional worker non-immigrant visa designation was TC, changing to TN in 1994 under the NAFTA Implementation Act. 
The Impact of Currency Exchange Rates and Canadian and U.S. Unemployment Rates on Non-Immigrant Visas from Canada to the U.S.

\section{References}

Baker, M., and Benjamin, D. 1996. Asia Pacific immigration and the Canadian economy. In R. G. Harris (Ed.), The Asia Pacific region in the global economy: A Canadian perspective, pp. 303-356. Calgary, AB: University of Calgary Press.

Devoretz, D., and Laryea, S. 1997. Are we losing it? Canada's brain drain to the United States: New evidence from the 1990s. Toronto: CD Howe Institute.

Devoretz, D., and Laryea, S. 1998. Canadian human capital transfers: The USA and beyond. Paper presented at the Fraser Institute Conference on the Brain Drain: Causes, Consequences and Policy Response, Vancouver, BC, November 23, 1998.

Dorantes, C. A., and Huang, W. C. 1997. Unemployment, immigration, and NAFTA: A panel study of ten major U.S. industries. Journal of Labor Research, 18: 613-619.

Foxall, G. F., and James, V. K. 2003. The behavioral ecology of brand choice: how and what do consumers maximize? Psychology and Marketing, 20: 811-816.

Globermann, S. 1999. Perspectives on North American free trade: Trade liberalization and the migration of skilled workers. Industry Canada Research Publications Program. Paper No. 3.

(Available at www.ic.gc.ca/epic/site/eas-aes.nsf/en/ra01770e.html)

Han, J. D., and Ibbott, P. 2005. Korean migration to North America: Some prices that matter. Canadian Studies in Population, 32: 155-176.

Harper, D. 1995. How will NAFTA affect you? Industrial Distribution, 84, 90.

Harris, J. R., and Todaro, M. P. 1970. Migration, unemployment and development: A two-sector analysis. American Economic Review, 60: 126-142.

Herrnstein, R. J. 1961. Relative and absolute strength of response as a function of frequency of reinforcement. Journal of Experimental Analysis of Behavior, 4: $267-272$.

Iqbal, M. 2000. The migration of high-skilled workers from Canada to the United States: Empirical evidence and economic reasons. Center for Comparative Immigration Studies, University of California, San Diego. (Available at http://repositories.cdlib.org/papers/wrkg20).

Marr, W., and Siklos, P. 1994. The link between immigration and unemployment in Canada. Journal of Policy Modeling, 16: 1-25.

Riddell, W. C. 2005. Why is Canada's unemployment rate persistently higher than that in the U.S.? Canadian Public Policy, 31: 93-100. 
Smith, C. I., and Hantula, D. A. 2003. Pricing effects on foraging in a simulated Internet shopping mall. Journal of Economic Psychology, 24: 653-674.

United States Code of Federal Regulations. 2008. Title 8, Aliens and nationality. Office of the Federal Register National Archives and Records Administration. Washington, DC: U.S. Printing Office.

\section{Appendix}

1. Source of currency exchange rates: Annual mean currency exchange rates were obtained from the Bank of Canada (www.bankofcanada.ca/en/rates/exchange.html) and OANDA.COM: (www.oanda.com/fxhistory).

2. Source of Canadian and U. S. unemployment rates: Human Resources and Development Canada:

(http://www4.hrsdc.gc.ca/indicator.jsp?lang=en\&preview=1\&indicatorid=16) and the U.S. Bureau of Labor Statistics (http://www.stats.bls.gov).

3. Source of non-immigrant visa numbers: Non-immigrant visa numbers were obtained from the U.S. Department of Homeland Security:

(http://www.dhs.gov/ximgtn/statistics/publications/yearbook.shtm). 